\title{
Analysis of the Government's Crisis Communication Strategy Discourse to Defend Covid-19
}

\section{Analisis Wacana Strategi Komunikasi Krisis Pemerintah Menangani Covid-19}

\author{
Anton Surahmat ${ }^{1}$, Susanne Dida ${ }^{2}$, Feliza Zubair ${ }^{3}$ \\ ${ }^{1}$ Universitas Padjadjaran, Jl. Raya Bandung Sumedang KM.21, Hegarmanah, Jatinangor, \\ Kabupaten Sumedang, Jawa Barat 45363* \\ Email: surahmatanton@gmail.com \\ ${ }^{2}$ Universitas Padjadjaran, Jl. Raya Bandung Sumedang KM.21, Hegarmanah, Jatinangor, \\ Kabupaten Sumedang, Jawa Barat 45363 \\ Email: susanne.dida@unpad.ac.id \\ ${ }^{3}$ Universitas Padjadjaran, Jl. Raya Bandung Sumedang KM.21, Hegarmanah, Jatinangor, \\ Kabupaten Sumedang, Jawa Barat 45363 \\ Email: feliza.zubair@unpad.ac.id
}

Masuk tanggal : 21-09-2020, revisi tanggal : 08-01-2021, diterima untuk diterbitkan tanggal : 19-02-2021

\begin{abstract}
Crisis communication is one of the most important instruments in crisis management. Unfortunately, there is a lot of criticism about how the Indonesian government implemented its crisis communication strategy during the Covid-19 pandemic season. This study aims to uncover the government's crisis communication strategy from the perspective of Van Dijk's critical discourse analysis on text and social context dimension. Based on the Situational Crisis Communication Theory (SCCT), researchers study the structure of discourse in texts consisting of macro, superstructure, and micro. There were 6 press releases from President Jokowi, Minister of Health Terawan Agus Putranto, and Spokesperson dr. Achmad Yurianto was collected using a purposive sampling method to describe the government's crisis communication strategy at the beginning of pre-crisis and crisis. The results show a significant dynamic crisis communication strategy on how the government implemented it in the pre-crisis and crisis phases. In the pre-crisis phase, they were statements from public officials especially in this case coming from President Jokowi and Minister of Health Terawan Agus Putranto. Both of these statements tend to lead to Deny and Diminish's strategy while still delivering messages in the form of Adjustments and Instructive Information so that the public remains alert and calm. However, in the crisis phase, government communication shifted towards Diminishes' statement, in the view of Justification that the crisis was actually not so terrible and bad. This is the biggest idea that emerged in the statement of President Jokowi and Spokesperson dr. Achmad Yurianto. Broadly speaking, this phase also provides a greater perspective on projections of government policy in the Covid-19 arrangement.
\end{abstract}

Keywords: Covid-19, crisis communication, government, SCCT, Van Dijk

\section{Abstrak}

Komunikasi krisis adalah salah satu instrumen terpenting dalam manajemen krisis. Sayangnya, selama pandemi Covid-19 melanda Indonesia, strategi komunikasi krisis 
pemerintah mendapatkan kritikan dari banyak pihak. Penelitian ini bertujuan untuk menguak strategi komunikasi krisis pemerintah dengan metode Analisis Wacana Kritis Van Dijk yang berfokus pada dimensi teks dan konteks sosial. Berdasarkan telaah Situational Crisis Communication Theory (SCCT), peneliti mengkaji struktur wacana dalam teks yang terdiri dari aspek makro, superstruktur dan mikro. Enam keterangan pers dari Presiden Jokowi, Menteri Kesehatan Terawan Agus Putranto, dan Juru Bicara dr. Achmad Yurianto dipilih dengan metode purposive sampling guna menggambarkan strategi komunikasi krisis pemerintah pada fase prakrisis dan krisis. Hasilnya, Strategi komunikai krisis pemerintah sejak fase prakrisis hingga krisis mengalami dinamika dari segi implementasi SCCT. Pada fase prakrisis, pernyataan pejabat publik khususnya dalam hal ini Presiden Jokowi dan Menteri Kesehatan Terawan Agus Putranto mengarah pada bentuk - bentuk Deny dan Diminish. Sembari tetap menyertakan strategi komunikasi berupa Adjusting Information dan Instructive Information demi memberikan informasi kepada publik agar tetap tenang dan waspada. Namun pada fase krisis, komunikasi pemerintah bergeser dalam rupa pernyataan Diminish saja dimana Justification bahwa Covid-19 tidak semenakutkan apa yang diberitakan menjadi gagasan utama yang muncul pada pernyataan Presiden Jokowi dan Jubir dr. Achmad Yurianto. Pemerintah justru gagap dan tidak konsisten dalam mengomunikasikan kebijakannya terkait penanganan COVID-19 selama prakrisis dan krisis sehingga menimbulkan keresahan baik berupa misinformasi maupun disinformasi di masyarakat.

Kata Kunci: Covid-19, komunikasi krisis, pemerintah, SCCT, Van Dijk

\section{Pendahuluan}

Wacana "Menganggap enteng" sempat mengemuka seiring dengan fleksibelnya gaya komunikasi krisis yang diterapkan oleh pemerintah (Abadi, 2020). Kesehatan Terawan Putranto secara santai menanggapi isu "Indonesia kebal Covid-19" dengan menyatakan bahwa itu merupakan berkat dari do'a seluruh rakyat Indonesia (Pramudiarja, 2020). Tidak berhenti di situ, pejabat lain Menteri Perhubungan Budi Karya Sumadi bahkan berkelakar bahwa Covid-19 tidak mempan kepada orang Indonesia karena kebiasaan mengkonsumsi nasi kucing (Priatmojo, 2020).

Beragam pernyataan kontroversial lainnya terus tercatat muncul dari keterangan pejabat publik sejak Januari hingga akhir Februari. Pernyataan pernyataan semacam ini kemudian berkurang dan tidak banyak muncul setelah fase krisis Covid-19 bermula dengan rilis informasi temuan kasus pertama dan kedua di Indonesia pada 2 Maret 2020. Apakah ini merupakan kegagapan pejabat publik dalam merespons pandemi Covid-19 seperti yang banyak disinggung media? Atau justru merupakan strategi komunikasi krisis yang sengaja dibangun demi menjaga dimensi lain yang dipandang utama yaitu stabilitas ekonomi?

Pada titik inilah analisis wacana dibutuhkan. Pemahaman Foucault mengenai wacana dijelaskan (dalam Matheson, 2005), Foucault menyatakan bahwa mempelajari teks tidak seharusnya hanya sebagai suatu dokumen melainkan sebagai wacana yang menjadi bagian dari suatu jaringan identitas dan kekuasaan. Teks tidak hanya diinterpretasikan tapi dipelajari sebagai bagian dari upaya opresi yang tengah terjadi, prasangka, hingga upaya untuk mendapatkan kekuasaan lewat pengetahuan. 
Eriyanto menjelaskan analisis wacana dalam 3 sudut pandang mengenai bahasa. Pertama, bahasa sebagai jembatan antara manusia dengan objek yang berada di luar dirinya. Wacana diukur lewat pertimbangan benar atau tidak berdasarkan sintaksis dan semantiknya. Kedua, bahasa merupakan episentrum kegiatan wacana serta kaitannya dengan hubungan sosial. Sehingga wacana adalah analisis untuk membongkar maksud - maksud atau makna - makna tertentu yang mungkin terselubung dan ketiga, bahasa merupakan representasi yang berdaya bentuk subjek berupa tema - tema atau strategi - strategi tertentu. Analisis wacana berperan dalam membongkar kuasa yang ada dalam proses bahasa (Ismail, 2008).

Tepatlah kiranya analisis wacana digunakan sebagai 'pisau bedah' demi mengungkap strategi komunikasi yang dijalankan. Praktik komunikasi ini terutama para pelaku komunikasi seperti humas, media massa, periklanan hingga tentu saja pemerintah mengemas pesannya demi memperoleh tujuan - tujuan komunikasinya (Hamad, 2006). Pesan tidak hanya ditampilkan tetapi 'dirancang' dengan landasan visi dan misi strategis. Karena itulah, analisis wacana mengetengahkan perspektif lain bahwa komunikasi sebagai wacana 'Communication as discourse' (Hamad, 2006). Memahami secara mendalam apa yang ditampilkan pada teks - teks narasi pernyataan pemerintah dapat membantu masyarakat memahami bagaimana sebenarnya komunikasi krisis yang diimplementasikan selama masa pandemi Covid-19 ini.

Krisis Covid-19 yang melanda tanah air memiliki dampak destruktif bagi perekonomian bangsa. Kesalahan dalam penanganannya bisa mengakibatkan keterpurukan ekonomi yang berujung pada krisis ekonomi yang bahkan lebih buruk dari krisis moneter 1998 (Resti, 2020). WHO menginstruksikan setiap negara menerapkan kebijakan untuk mengurangi, memperlambat, dan menghentikan laju penyebaran COVID-19 (Christin et al., 2021). Sebuah laporan Deep Knowledge Group yang dimuat di Forbes pada 13 April 2020 mengkategorikan Indonesia sebagai salah satu negara yang memiliki resiko kegagalan tertinggi dalam penanganan Covid-19 (Colangelo, 2020). Laporan global Forbes tersebut mendeskripsikan situasi genting mengenai adanyak krisis kebijakan dalam menanganani pandemi Covid-19 dan menempatkan Indonesia di peringkat ke-19 dari 20 negara Asia Pasifik.

Namun demikian, pemerintah sejatinya mengimplementasikan berbagai kebijakan yang menjadi cerminan manajemen krisis Covid-19. Pada fase prakrisis ketika Wuhan mulai melaksanakan peraturan lockdown atau karantina, pemerintah telah berhasil memulangkan 238 WNI dari episentrum Covid-19 tersebut. Respons yang bahkan mendapatkan apresiasi dari WHO (Ramdhani, 2020). Pemerintah juga membentuk dan mengaktifkan Tim Gerak Cepat (TGC) di wilayah - wilayah otoritas pintu masuk negara seperti bandara, pelabuhan dan berbagai pos lintas batas darat negara (PLBDN). Tim yang terdiri dari Kantor Kesehatan Pelabuhan (KKP), Imigrasi, Bea Cukai, Karantina Hewan dan unit lain yang memiliki kompetensi pencegahan masuknya Covid-19 ke Indonesia.

Pemerintah menjalankan prosedur - prosedur pemeriksaan kesehatan seperti pemindaian suhu tubuh di 135 titik bandara udara, darat dan pelabuhan. Penunjukan 100 Rumah Sakit (RS) rujukan Covid-19. Hingga penundaan seluruh 
penerbangan dari dan menuju Tiongkok sejak 5 Februari 2020 (Kementerian Luar Negeri, 2020). Pada sektor ekonomi yang rawan dihantam pandemi, pemerintah juga menggodok berbagai kebijakan fiskal yang berusaha menahan laju perlambatan ekonomi karena pagebluk Covid-19. Sektor ekonomi ini memang menjadi salah satu yang terdampak parah pandemi Covid-19. Dalam salah satu seminar yang diselenggarakan LIPI, disebutkan bahwa potensi kerugian ekonomi pada sektor pariwisata mencapai \$2 Milyar. Sektor lain yang terdampak langsung ialah perdagangan dan konsumsi dimana $13 \%$ jenis barang ekspor ke Tiongkok terkena imbasnya. Dan 6,5\% impor dari Tiongkok berpotensi hilang dari pasar domestik Indonesia. Ini akan berdampak pada konstraksi pertumbuhan ekonomi Indonesia pada Tahun 2020 (LIPI, 2020).

Pada awal fase krisis yang ditandai dengan pengumuman 2 pasien pertama Covid-19 di Indonesia, pemerintah bergerak cepat dengan menetapkan Peraturan Presiden No. 52 Tahun 2020 tentang pembangunan fasilitas observasi dan penampungan di Pulau Galang, Kota Batam (Peraturan Presiden No. 52 Tahun 2020, 2020). Hanya dalam waktu kurang lebih 1 bulan. Rumah sakit ini telah siap dan beroperasi sejak 6 April 2020 (Aulawi, 2020). Tidak hanya di Pulau Galang, pemerintah juga terus menambah jumlah rumah sakit rujukan bagi pasien Covid19. Hingga saat ini ada 800 rumah sakit rujukan baik milik pemerintah pusat, pemerintah daerah, BUMN, TNI-Polri, maupun swasta yang beroperasi di seluruh wilayah Indonesia (Yahya, 2020).

Presiden Joko Widodo (Jokowi) juga segera membentuk Gugus Tugas Percepatan Penanganan Covid-19 yang dipimpin oleh Kepala Badan Nasional Penanggulangan Bencana (BNPB) Doni Monardo (Keppres No. 7 Tahun 2020, 2020). Tercatat ada sedikitnya 52 regulasi terkait Covid-19 yang telah diluncurkan pemerintah sebagai bagian dari penanganan pagebluk ini (Covid19, 2020).

Presiden juga pada akhirnya kembali merilis kebijakan ekonomi pada masa pandemi. Dengan total anggaran mencapai Rp. 405,1 Triliun, ada 11 poin utama yang menjadi fokus implementasi dalam penanganan Covid-19 ini yaitu: (1) Dukungan terhadap bidang kesehatan, (2) Insentif bulanan tenaga medis, (3) Perlindungan sosial, (4) Tarif listrik, (5) Kenaikan anggaran kartu prakerja, (6) Pemulihan ekonomi, (7) Antisipasi deficit APBN, (8) Keringanan angsuran nasabah, (9) Bidang non-fiskal, (10) Refokusing dan realokasi belanja, dan (11) Penyiapan perppu (Dhyaksa, 2020).

Sekilas rangkaian kebijakan pemerintah di atas adalah gambaran dari suatu manajemen krisis. Manajemen krisis adalah upaya khusus dan terukur yang diambil dalam rangka menyelesaikan masalah yang disebabkan oleh sebuah krisis (Devlin, 2007). Sementara menurut Coombs, manajemen krisis adalah serangkaian faktor yang dirancang untuk melawan krisis dan mengurangai dampak kerusakan yang ditimbulkannya. Lebih jauh, ia menjelaskan manajemen krisis sebagai suatu upaya untuk mencegah atau mengurangi hasil negatif akibat krisis sehingga bisa melindungi pula organisasi, para pemangku kepentingan, dan/atau industri dari kerusakan (T. W. Coombs \& Holladay, 2011).

Salah satu bagian krusial dalam perencanaan manajemen krisis yang baik adalah komunikasi krisis. Faktanya, komponen kritis dalam suatu manajemen krisis adalah komunikasi (T. W. Coombs \& Holladay, 2011). Pada intinya, 
komunikasi krisis adalah segala bentuk komunikasi yang dilakukan oleh organisasi kepada para pemangku kepentingannya baik sebelum selama dan sesudah periode buruk tersebut berlangsung (Fearn-banks, 2011). Pada masa pandemi Covid-19 ini, pemerintah pada akhirnya menunjuk 1 Juru Bicara (Jubir) dr. Achmad Yurianto selaku komunikator utama Gugus Tugas Percepatan Penanganan Covid-19 yang diikuti penambahan dr. Raisa Asmara Subroto sebagai Jubir kedua.

Kendati demikian, publik telah terlanjur mencap pemerintah tidak serius dalam komunikasi publiknya dalam hal ini tentu saja komunikasi krisis. Terutama pada fase prakrisis dimana banyak pernyataan pejabat publik yang dianggap blunder. Berbagai artikel ilmiah juga mengkritisi buruknya komunikasi pemerintah. Salah satunya datang dari Fakhruroji dkk yang membahas strategi komunikasi publik dari perspektif sosiologi komunikasi massa dan agama (Fakhruroji et al., 2019).

Komunikasi adalah salah satu bentuk interaksi (University of Minnesota, 2016). Demikian juga dengan wacana yang merupakan suatu bentuk interaksi (Juditha, 2018). Sementara Lull (dalam Juditha, 2018) menyebut wacana adalah gagasan yang dibicarakan secara terbuka kepada khalayak sehingga menimbulkan pemahaman tertentu yang kemudian tersebar secara luas. Renkema dalam (Mardikantoro \& Santoso, 2017) mengatakan bahwa wacana dipandang sebagai suatu pantulan dari sebuah relasi kekuasaan komunitas atau masyarakat. Komunikasi dipandang sebagai suatu upaya menciptakan "Realitas lain" atau "Realitas kedua" melalui pembentukan suatu wacana sebagai pengganti "Realitas pertama" (Hamad, 2006).

Menarik untuk disimak bagaimana wacana pemerintah dalam menangani wabah Covid-19 yang tercermin dari strategi komunikasi krisis yang dijalankan selama ini. Meskipun wabah atau penyakit bukan merupakan kesalahan yang dilakukan oleh pemerintah. Pemerintah sendiri bahkan menjadi korban, tetapi tetap saja bisa disalahkan apabila gagal atau tidak mampu menguasai keadaan secepatnya (Fearn-banks, 2011). Analisis wacana kritis dengan metode Van Dijk akan mengupas bagaimana strategi komunikasi krisis yang dijalankan pemerintah dalam perspektif Situational Crisis Communication Theory (SCCT) (W. T. Coombs, 2007), selama fase prakrisis dan krisis pagebluk Covid-19 di Indonesia. Riset ini bertujuan untuk membedah bagaimana strategi komunikasi krisis pemerintah terkait penanganan Covid-19 dari dimensi analisis teks dan konteks sosial Van Dijk.

\section{Metode Penelitian}

Penelitian ini menggunakan pendekatan kualitatif dan mengimplementasikan analisis metode paradigmatik dengan cara menemukan bukti/evidensi dalam naskah atau menunjukan bagian - bagian dari naskah sebagai temuan riset untuk menjawab permasalahan penelitian (Hamad, 2007). Metode analisis wacana yang digunakan ialah AWK Van Dijk. Metode ini (dalam Lado, 2014) menggaris bawahi krusialnya penelitian wacana yang tidak hanya berkisar pada teks melainkan juga praktik produksinya. 
Wacana dalam konteks Van Dijk memiliki 3 dimensi meliputi teks, kognisi sosial, dan konteks sosial (T. Van Dijk, 1993). Kendati demikian riset ini sendiri berfokus pada 2 elemen utama AWK yaitu dimensi teks dan dimensi konteks sosial. Ada 3 elemen pada kajian teks AWK Van Dijk yaitu Struktur Makro, Superstruktur, dan Struktur Mikro (Juditha, 2018). Sementara dimensi konteks sosial mencakup fenomena yang pada saat itu tengah terjadi di masyarakat (Nurlaily, 2019) dalam hal ini pandemi COVID-19.

Sebagaimana ditegaskan Van Dijk dalam Kustiyono, (2010) bahwa salah satu prinsip analisis wacana adalah strategi. Strategi diaplikasikan oleh pengguna bahasa dalam memahami dan menakrifkan wacana serta realisasi tujuan - tujuan komunikatif serta sosialnya. Karena itulah, teori SCCT menjadi panduan dalam membedah bagaimana strategi komunikasi krisis yang dijalankan pemerintah selama masa prakrisis dan krisis pandemi Covid-19 ini berlangsung.

Analisis wacana kritis Van Dijk adalah analisis yang fokus pada bagaimana makna suatu kalimat atau ujaran diorganisasikan ke dalam struktur penalaran yang lebih luas (Makrostruktur) (Matheson, 2005). Kata - kata, klausa dan ekspresi tekstual lainnya mungkin dapat menyiratkan konsep dan proposisi yang bisa disimpulkan berdasarkan konteks atau latar belakang. Selain itu, analisis dari hal yang 'tidak terkatakan' terkadang bisa lebih mengungkapkan daripada studi yang apa benar - benar diekspresikan di dalam teks (Matheson, 2005).

Analisis teks pada wacana kritis Van Dijk fokus pada 2 tahapan struktur semantik meliputi struktur makro dan struktur mikro (Kintsch \& Dijk, 1978). Sementara superstruktur merupakan skema keseluruhan yang ditemukan pada struktur makro (T. A. van Dijk, 1983). Ketiga bagian ini menjadi fokus utama dalam membedah bagaimana produksi teks dari pemerintah berlangsung. Terutama pada fase prakrisis dan krisis pagebluk Covid-19. Pada struktur makro hal yang diperhatikan adalah topik/tema keseluruhan. Pada level superstruktur hal yang diperhatikan ialah skema atau urutan narasi teks secara utuh. Sedangkan pada level struktur mikro, elemen yang diperhatikan meliputi aspek semantik, stilistik, sintaksis, dan retoris.

Analisis teks juga melibatkan konteks atau faktor - faktor yang melatarbelakangi kemunculan teks tersebut. Dalam konteks situasi pandemi Covid-19, strategi komunikasi krisis pemerintah mendapatkan banyak perhatian dan kritikan (The Conversation, 2020). Teknik pengumpulan data melibatkan studi pustaka dimana subjek penelitian yaitu 6 keterangan pers yang dirilis oleh Presiden Republik Indonesia Joko Widodo, Menteri Kesehatan Terawan Agus Putranto, dan Juru Bicara pemerintah untuk Gugus Tugas Percepatan Penanganan Covid-19 Achmad Yurianto. Peneliti merekam 6 pernyataan keterangan pers masing - masing pada fase prakrisis dan krisis dari berbagai sumber terutama kanal Youtube resmi pemerintah yaitu Sekretariat Presiden, Sekretariat Kabinet, dan Sekretariat Presiden. Serta dari saluran berita meliputi CNBC dan Berita Satu. Semua sumber tersebut dipilih karena merepresentasikan keterangan lengkap narasumber yang tidak bisa ditemukan pada sumber - sumber lainnya.

Pengambilan sampel berupa purposive sampling; maximum variation sampling dimana peneliti berusaha mengidentifikasi kasus/teks dengan berbagai karakteristik berbeda untuk memaksimalkan keberagaman dalam sampel demi 
mendapatkan jangkauan perspektif seluas mungkin (Hancock et al., 2007). Keabsahan data diperoleh melalui triangulasi sumber dari berbagai kanal pemberitaan baik laman daring maupun situs pemerintah resmi. Peneliti memanfaatkan bantuan perangkat lunak analisis data Atlas.ti untuk melakukan kategorisasi dan analisis pada kode - kode yang telah dibuat untuk kemudian disajikan.

\section{Hasil Penemuan dan Diskusi}

\section{Kajian Analisis Teks Pada Fase Prakrisis Struktur Makro:}

Pada 6 Maret 2020, Kantor Staf Presiden (KSP) menerbitkan protokol komunikasi publik Covid-19 (KSP, 2020). Protokol komunikasi ini diluncurkan sebagai petunjuk teknis terutama bagi pemerintah pusat dan pemerintah daerah dalam merespons dan menyampaikan informasi terkait Covid-19 kepada masyarakat. Pemerintah hendak mendiseminasikan narasi utama dalam bentuk "Pemerintah Serius, Siap, dan Mampu Menangani Covid-19", "Masyarakat Tetap Tenang dan Waspada", "Covid-19 Bisa Sembuh" dengan tanda pagar \#LAWANCOVID19.

Hal ini bisa jadi merupakan sebuah respons pemerintah atas tidak memadainya komunikasi publik yang dibangun selama fase prakrisis dan permulaan krisis berlangsung. Banyaknya pernyataan pejabat publik yang membingungkan dan terkesan meremehkan memantik beragam kritikan dan prasangka akan keseriusan pemerintah menangani ancaman pandemi Covid-19. Salah satu lembaga pemerhati kebijakan pemerintah LP3ES bahka merilis setidaknya 37 pernyataan blunder pemerintah tentang Covid-19 selama kurun waktu 1 Januari - 5 April 2020 (Mawardi, 2020).

Amalinda dan Dias dalam (Mas'udi \& Winanti, 2020), memperhatikan bahwa pada fase prakrisis pemerintah cenderung abai dan bersikap 'anti ilmu pengetahuan'. Situasi ini berlangsung antara Desember 2019 hingga Februari 2020. Barulah pada fase krisis, respons pemerintah lebih pro terhadap ilmu pengetahuan dengan mengambil kebijakan berdasarkan pengetahuan yang ada. Fase ini mulai bermula setidaknya sejak awal krisis yang ditandai dengan pengumuman 2 kasus pertama positif Covid-19 di Indonesia.

Menkes Terawan turut menjelaskan bagaimana situasi kondisi penanganan WNI yang dievakuasi dan menjalani karantina di Pulau Natuna (Ramdhani, 2020). Ada juga keterangan pers mengenai pernyataan Menkes Terawan tentang hasil penelitian Profesor Marc Lipsitch dari Harvard University yang menganalisis permodelan penyebaran Covid-19 berdasarkan volume penerbangan dari Wuhan ke berbagai destinasi internasional termasuk Indonesia (Lipsitch et al., 2020). Pada rekomendasi tulisannya, March mendorong pemerintah Indonesia yang pada saat itu nihil kasus Covid-19 memperkuat pengawasan dan langkah - langkah kontrol yang tepat untuk mengurangi resiko penularan mandiri. 


\section{Superstruktur:}

Pada tatanan superstruktur Terawan Putranto menjabarkan kronologi singkat proses evakuasi para WNI karantina Natuna ke Halim Perdanakusumah. Isi pernyataannya secara garis besar menekankan bahwa proses karantina berlangsung sukses dan para WNI pulang dalam keadaan sehat. Terawan juga mengetengahkan fakta bahwa bersama rombongan turut hadir representasi WHO Paranie yang Terawan sebut menyaksikan dan turut berbahagia dengan keberhasilan ini. Pada akhir pernyataan pembukanya, Terawan menegaskan kembali bahwa implementasi protokol kesehatan Covid-19 di Indonesia transparan dan bersyukur proses karantina sukses atas andil doa rakyat Indonesia. Ada pula pernyataan presiden mengawali dengan menekankan pentingnya kewaspadaan dalam bentuk pengawasan pintu - pintu gerbang dari dan menuju Indonesia. Pada saat itu jumlah infeksi sudah mencapai 2,7 ribu jiwa (Aida, 2020) dengan total kematian mencapai 80 orang dan telah menginfeksi 15 negara (The Guardian, 2020). Lima hari sebelumnya, Wuhan episentrum Covid-19 telah menetapkan karantina penuh (Lockdown) guna memutus penyebaran Covid-19 (World Economic Forum, 2020).

Dalam bahasan Superstruktur Menkes Terawan secara gamblang menyebut pernyataan Marc adalah sebuah bentuk penghinaan dan pendiskreditan kemampuan Indonesia dalam menjalankan protokol kesehatan. Pernyataan lain tentang "Isu kekuatan do'a" ini secara tersirat merupakan kelakar yang menunjukan ketidaktahuan menkes tentang isu yang berkembang. Di satu sisi mungkin Terawan ingin masyarakat mempercayai bahwa doa adalah obat kebal Covid-19 atau di sisi lain Terawan ingin masyarakat tetap percaya dengan teori tersebut sehingga tidak terjadi kepanikan yang memperkeruh kestabilan ekonomi. Sehingga menkes tidak mematahkan secara lugas isu tersebut. Menkes mempersilakan masyarakat untuk mengikuti aktivitas ramai dan bekerumun seperti menonton konser. Ia ingin mengindikasikan bahwa Indonesia aman. Bebas Covid-19.

\section{Struktur Mikro:}

Kajian mikro pada tatanan semantik menyiratkan bahwa apa yang terjadi pada 285 WNI yang menjalani karantina adalah tanggung jawabnya. Glorifikasi keberhasilan 285 WNI yang dikarantina di Natuna. Disertai sinyalemen transparansi protokol yang berlangsung. Lalu pada sesi wawancara: Menkes menegaskan bahwa seluruh WNI dari karantina Natuna sehat. Ini lagi - lagi bentuk pengisbatan bahwa masyarakt tidak perlu khawatir dengan Covid-19. Buktinya yang karantina saja semuanya sehat negatif Covid-19.

Terawan menegaskan dan secara terbuka "Menantang" pihak Harvard University untuk melihat langsung bagaimana implementasi aturan kesehatan dan penggunaan alat - alat berlangsung. Pada aspek Leksikon, kata "Menghina", "Mendiskreditkan", disebut beberapa kali sebagai bentuk afirmasi keseriusan pemerintah atas banyak pemberitaan yang beredar mempertanyakan kemampuan dan keseriusaan pemerintah mengantisipasi Covid-19. Gaya bahasa santai dengan pelafalan aksen daerah yang kental seperti "Wong", "Yo", dan "Ndak" 
memberikan impresi kedekatan dengan masyarakat dan menyiratkan ketiadaan kekhawatiran atas Covid-19 bagi Indonesia.

Pada kajian Sintaksis Ada 7 kalimat pada bagian pembuka. Sebagian besar merupakan susunan kalimat majemuk yang terdiri dari 2 klausa atau lebih dengan isi kalimat berita. Pada sesi wawancara 14 kali Menkes menggunakan kata ganti "Saya" dan cuma sekali memakai kata ganti "Aku". Sementara tatanan stilistik memperlihatkan kata "Berbahagia dan mengharukan" menandakan perasaan sentimentil bahwa proses karantina yang dijalani adalah klimaks dan pembuktian bahwa Covid-19 masih merupakan sesuatu yang belum ada di Indonesia. Cukup sering Menkes memilih diksi "Terbuka" dan frase "Tidak ada yang disembunyikan" adalah sinyalemen jawaban atas segala tuduhan yang sebelumnya banyak beredar tentang kemampuan Indonesia dalam mendeteksi Covid-19.

Istilah Surveillance Tracking juga menarik sebagai simbol bahwa tidak perlu tindakan/pengawasan kesehatan berlebihan karena para WNI karantina sudah benar - benar sehat. Duta Kesehatan adalah gelar yang disematkan kepada WNI yang telah melewati karantina sebagai apresiasi sekaligus "Agen" pemerintah dalam menyebarluaskan informasi terkait Covid-19. Sekaligus pernyataan tidak langsung bahwa Covid-19 belum ada di Indonesia.

Diksi do'a menjadi salah satu perdebatan di media massa sebagai argumentasi atau alasan Indonesia belum terpapar Covid-19. Jika ditilik lebih dalam pilihan kata ini bisa jadi menyiratkan kepasrahan pemerintah karena tidak tahu kapan dan akan seperti apa pandemi ini bergerak. Dalam tatanan Retoris sebagaimana gaya khas Menkes Terawan dengan santai berbicara dengan aksen jawa yang kental. Terawan tersenyum dan tidak sungkan melempar guyonan kepada wartawan. Ini menyiratkan kepercayaan dirinya sebagai menteri kesehatan terkait langkah - langkah yang telah diambil.

Terawan juga tidak segan menggunakan repetisi dan klimaks seperti dalam kalimat "Sangat berbahagia... bertemu keluarga... sangat sehat". Menkes juga menggunakan majas Retorika dengan menanyakan untuk menegaskan standing point keyakinannya bahwa turis Cina tersebut tidak terinfeksi di Indonesia. Penggunaan Sinisme turut dipakai untuk menyalahkan oknum yang membeli masker sehingga harga masker melonjak.

Presiden Jokowi memaknai bahwa ini adalah momen prayitna bagi pemerintah. Dirinya menyatakan kesiapan sarana dan prasarana mengantisipasi ancaman Covid-19 sudah dalam kondisi siaga. Penekanana diksi "Waspada" dan "Hati - hati" ditegaskan pada awal dan akhir pernyataannya. Tidak luput presiden menyampaikan paparannya secara santai dengan penekanan frekuentif dan komparatif. Secara keseluruhan, strategi komunikasi yang dijalankan ialah Instructive Information dan Adjustment Information dimana pemerintah mengaku telah siap menghadapi ancaman Covid-19. Namun demikian, secara eksplisit Presiden Jokowi juga menolak "Disalahkan" apabila pada akhirnya Covid-19 menjangkiti. Bentuk "Deny" ini berupa "Denial" bahwa 'alat' bisa menjadi faktor menyebabkan Covid-19 tidak terdeteksi dan masuk ke Indonesia. 


\section{Konteks Sosial:}

Pendekatan kontekstual mengenai konteks secara umum mengasumsikan kurang lebih hubungan langsung antara situasi masyarakat, situasi politik atau kebudayaan dengan wacana itu sendiri (T. A. Van Dijk, 2006). Pada masa prakrisis, sebaran pandemi COVID-19 pada saat pernyataan - pernyataan tersebut dirilis belum masuk ke wilayah Indonesia atau setidaknya memang belum terdeteksi. Pada saat itu, pemerintah tengah berupaya untuk menjaga laju stabilitas pertumbuhan ekonomi yang tengah positif. Upaya ini bisa saja menjadi sia - sia apabila pasar merespon negatif kehadiran COVID-19 di Indonesia. Agresifnya kemampuan Reproduction Rate COVID-19 menekan pemerintah untuk bisa meyakinkan masyarakat dan pasar bahwa Indonesia "Aman" dari COVID-19. Pemerintah pada saat itu juga menggodok agenda - agenda lain yang bisa saja terpengaruh apabila COVID-19 pada akhirnya masuk ke Indonesia. Salah satunya tentu agenda pemindahan ibu kota negara dimana biaya yang perlu disiapkan tidaklah sedikit. Situasi yang berkembang pada saat itu justru memantik pemerintah mengeluarkan berbagai kebijakan pragmatis seperti insentif pariwisata untuk menarik wisatawan berkunjung di Indonesia. Sangat kontraproduktif dengan situasi keehatan global yang baru memasuki awal - awal pandemi.

\section{Strategi Komunikasi Krisis fase Prakrisis:}

Sementara dari analisis strategi komunikasi krisis versi SCCT, pernyataan Menkes Terawan merupakan Adjusting Information untuk mengonfirmasikan peralatan pengecekan yang dimiliki Indonesia sudah berstandar WHO dan bahkan berasal dari Amerika Serikat. Pada teks ini secara tersirat menkes menyuguhkan pengingkaran, strategi "Deny" berupa 'Attack the accuser' yaitu Marc Lipsitch yang dianggap menghina kapabilitas pemerintah dalam menjalankan protokol kesehatan WHO terkait deteksi Covid-19 (Rahayu, 2020).

Adjusting Information: Menkes Terawan sebagai mana dalam pendahuluannya menjelaskan kondisi situasi terkini WNI yang menjalani karantina di Natuna. Menkes juga berkali - kali menyatakan bahwa WNI dalam kondisi sehat dan prima. Malahan, ditunjuk sebagai duta kesehatan. Dalam konteks SCCT pernyataan - pernyataan Menkes Terawan merupakan bentuk Denial; diantaranya dengan menyalahkan wartawan dan secara umum; siapapun yang memakai masker padahal dalam keadaan sehat. Juga menyangkal apabila ada turis yang terinfeksi di Bali, dan mengkonfrontasi pertanyaan wartawan. Ini dikombinasikan dengan Diminish, berupa Deny Volition: Menyatakan bahwa apa yang terjadi adalah mekanisme pasar sehingga pemerintah tidak bisa berbuat apaapa untuk menginterupsi lonjakan harga masker di pasaran.

\section{Kajian Analisis Teks Pada Fase Krisis Struktur Makro:}

Fase krisis Covid-19 ditandai dengan ditemukannya 2 kasus awal Covid19 di Indonesia. Temuan ini juga sekaligus mendobrak segala isu "Kekebalan" yang pernah bergulir di media masa (Pramudiarja, 2020). Pemerintah langsung mengumumkan situasi ini melalui keterangan pers di Istana Negara. Utama ialah rilis informasi temuan kasus Covid-19 pertama di tanah air. Pemerintah secara 
tersirat menegaskan bahwa meskipun telah secara ketat mengawasi keluar/masuk orang di bandara tetapi tidak menutup kemungkinan adanya kegagalan. Ini pula yang melatarbelakangi temuan kasus Covid-19 di Indonesia. Meski demikian, lagi - lagi pemerintah menegaskan bahwa temuan ini juga berkat kesigapan pemerintah dalam melakukan pelacakan potensi penyebaran. Pada bagian penutup, Presiden kembali menegaskan kesiapan pemerintah dalam menangani ancaman Covid-19. Menurutnya, pemerintah telah menjalankan SOP yang sesuai dengan protokol internasional, peralatan, hingga anggaran telah disediakan.

Analisis kedua merupakan keterangan pers Presiden Jokowi keesokan harinya yaitu 3 Maret 2020. Secara makro, pernyataan presiden ini berkisar tentang situasi terkini upaya - upaya penanganan Covid-19. Terutama tentang bagaimana langkah - langkah pemerintah mengantisipasi penyebaran Covid-19 yang akhirnya telah masuk ke Indonesia. Kemudian dilanjut dengan permohonannya agar semua pihak bisa menjaga privasi pasien kasus 1 dan 2 . Presiden juga menghimbau masyarakat untuk mulai menerapkan pola hidup sehat, tidak panik dan memborong kebutuhan sehari - hari. Presiden juga mengancam para pelaku culas yang menimbun masker dan perlengkapan lain dengan hukuman tegas. Dalam penutupnya, Presiden Jokowi meminta masyarakat untuk meningkatkan solidaritas bersama dan percaya bahwa pemerintah tengah melakukan upaya - upaya terbaik untuk menanggulangi ancaman pandemi Covid19 ini.

Analisis ketiga menelaah teks keterangan pers pertama Juru Bicara resmi percepatan penanganan Covid-19 di Indonesia dr. Achmad Yurianto. Sean dan Engelhoff mengatakan bahwa posisi Jubir sangat penting karena ketika krisis meletus komunikasi adalah hal yang paling kritikal. Respons yang organisasi berikan haruslah cepat karena ini akan mempengaruhi impresi pertama masyarakat terhadap bagaimana organisasi menghadapi krisis (T. W. Coombs \& Holladay, 2011).

Kehadiran jubir mampu mengurangi kemungkinan pernyataan pernyataan yang justru menimbulkan konflik, nilai - nilai organisasi, atau penjelasan yang dirilis kepada media (Fearn-banks, 2011). Jubir dituntut untuk segera bertemu dengan media untuk mendiseminasikan informasi dan berpartisipasi dalam membingkai krisis. Segala pertanyaan harus dijawab dengan konsisten, akurat, cepat, dan terbuka (T. W. Coombs \& Holladay, 2011). Penunjukan dr. Achmad Yurianto pada 3 Maret secara resmi diperkenalkan Menteri Kesehatan Terawan Agus Putranto yang disambung dengan keterangan pers pertamanya sebagai Jubir resmi pemerintah untuk percepatan penanganan Covid-19 (Laksana, 2020).

\section{Superstruktur:}

Pada aspek superstruktur, Presiden Jokowi mengawali keterangan pers dengan menyampaikan topik ulasan langkah cepat pemerintah setelah kasus pertama dan kedua Covid-19 di Indonesia ditemukan. Presiden Jokowi menegaskan bahwa penelusuran kontak telak dijalankan sebagai salah satu upaya memutus mata rantai penyebaran Covid-19. Presiden Jokowi lalu meyakinkan masyarakat bahwa Covid-19 tidak semenyeramkan apa yang selama ini 
diberitakan. Presiden Jokowi merujuk Covid-19 sebagai flu biasa yang bisa sembuh. Isi pernyataan utama terkait penanganan pasien Covid-19 kasus 1 dan 2 menunjukan tanda - tanda positif. Jokowi menjelaskan bahwa para penderita tidak memiliki gejala berat dan hanya batuk ringan. Disusul dengan pemaparan hasil pemeriksaan spesimen yang ada hingga penanganan ABK WNI yang berada di kapal pesiar World Dreams dan Diamond Prince. Dalam pernyataan penutup sebelum sesi wawancara ia berharap para ABK dapat sehat bertahan karena situasi di kapal pesiar Diamond Prince lebih rawan dibanding Kota Wuhan sendiri sebagai episentrum Covid-19.

\section{Struktur Mikro:}

Pada aspek semantik, pemerintah menegaskan keseriusannya mengantisipasi Covid-19 dan telah menjalankan segala protokol kesehatan WHO. Ini sekaligus bantahan bahwa pemerintah menyepelekan Covid-19 sebagaimana muncul dalam banyak pemberitaan. Presiden Jokowi mengingatkan beberapa aktivitas yang telah dilakukan dalam rangka prediksi ancaman Covid-19 terhadap WNI. Jokowi beralasan tatkala 2 WNI positif namun hal tersebut bukan sepenuhnya salah pemerintah melainkan karena alat pengecekan. Dalam kajian semantik lain, Jubir mengawali dengan membeberkan situasi episentrum Covid19 yang sudah berkurang dan saat itu hanya meninggi di 4 negara saja.

Pada kajian sintaksis terdapat 49 kalimat, tapi hanya 33 kalimat yang berkorelasi dengan topik pembicaraan. Hampir seluruhnya berisikan kalimat berita. Presiden Jokowi menggunakan kata ganti "Saya" pada awal pernyataan sebanyak 5 kali dan 32 pronomina "Kita". Pronomina "Kita" bersifat inklusif; artinya, kata ganti ini melingkupi tidak saja pembicara/penulis, tetapi juga pendengar/pembaca dan mungkin pula pihak lain (Fitriyah, 2013). Sebaliknya, kata ganti "Kami" bersifat eksklusif yang bermakna terbatas bagi pembicara/penulis tanpa melibatkan pihak pendengar/pembaca.

Kajian aspek stilistik menguraikan diksi "Terkonfirmasi Positif" daripada "Tertular" atau "Menderita". Ini pilihan kata yang tepat dan lebih netral dibandingkan menggunakan kata seperti "Terjangkiti", "Tertular" yang lebih menimbulkan nuansa makna menyeramkan. Singkatnya, nuansa makna menurut Keraf dalam (Bangun, 2013) adalah suatu kemampuan menentukan kata/diksi yang sesuai dengan situasi dan nilai rasa yang dimiliki kelompok masyarakat pendengar. Kata "Penjara" dipilih untuk memaknai asumsi yang beredar di masyarakat bahwa yang sehat pun harus memakai masker padahal hanya yang sakit yang menurutnya wajib memakai masker.

Sedangkan kajian retoris meneguhkan gaya bahasa Presiden Jokowi berupa penegasan bahwa upaya penelusuran kontak benar - benar telah dijalankan untuk memutus rantai penyebaran. Majas Pleonasme dalam paraghraf ini adalah bentuk penegasan bahwa pemerintah siap dan sudah memastikan ketersediaan bahan pokok selama ancaman pandemi berlangsung. Jadi masyarakat tidak perlu melakukan "Pembelian panik". Ada proyeksi makna bahwa apa yang terjadi sekarang bisa saja bermuara pada situasi yang sama yaitu menjadi flu musiman biasa. Majas Pararelisme untuk meyakinkan dan menegaskan bahwa situasi pasien covid-19 kasus 1 dan 2 tidak kritis dan berbahaya. Majas Pleonasme bahwa 
penelusuran dan pemantauan dilakukan dengan amat serius. Majas Sinisme; menyindir mereka pengguna masker. Hingga penggunaan Majas Simile yang mengandaikan bahwa orang sakitlah yang wajib memakai masker. Bukan orang yang sehat. Virus yanga da pada orang sakit ibarat penjahatnya.

\section{Konteks Sosial:}

Pemerintah mengonfirmasi kasus positif pertama dan kedua di Indonesia. Pengumuman ini sekaligus mematahkan argumentasi - argumentasi serta berbagai berita bohong yang sebelumnya cukup banyak beredar terkait daya tahan tubuh orang Indonesia yang dianggap "Kuat" terhadap COVID-19. Situasi global pada 2 Maret 2020 juga semakin genting dimana jumlah pasien COVID-19 telah mencapai puluhan ribu dimana ratusan kasus positif telah ditemukan di negara tetangga Singapura. Masifnya misinformasi dan disinformasi terkait COVID-19 mendorong pemerintah pada akhirnya menunjuk Juru Bicara (Jubir) penanganan COVID-19 sebagai Langkah strategis komunikasi krisis yang terjadi. Pemerintah mulai menaruh perhatian lebih besar terhadap perkembangan pagebluk setelah berbagai kepanikan melanda masyarakat. Salah satunya praktik - praktik panic buying yang mengakibatkan stok - stok masker dan APD kesehatan menghilang dari pasar. Temuan kasus pertama dan kedua positif COVID-19 di Indonesia juga melatarbelakangi kebijakan - kebijakan pemerintah selanjutnya untuk lebih terbuka dan responsif dalam menangani COVID-19. Berbagai refocusing kebijakan dan anggaran disesuaikan untuk bisa secara langsung berguna dalam upaya meredam pagebluk COVID-19 yang terjadi.

\section{Strategi Komunikasi Pada Fase Krisis:}

Dalam kaidah SCCT, Presiden Jokowi mengeluarkan pernyataan berupa Adjusting Information, yakni Pemerintah menyerahkan informasi terkini penanganan Covid-19 terutama pada pasien kasus 1 dan 2 serta langkah - langkah preventif apa saja seperti penelusuran kontak, untuk memastikan mata rantai penyebaran bisa diputus. Instructive Information juga termanifestasi dalam penegasan presiden yang menginstruksikan perlindungan terhadap privasi.

Berbeda dengan fase prakrisis, pernyataan - pernyataan Presiden Jokowi pada momen ini lebih taktis. Interpretasi maklumat yang Jokowi sampaikan merupakan bentuk Adjusting Information dan Instructive Information. Ini sesuai dengan kondisi awal krisis yang menimbulkan banyak misinformasi dan disinformasi di masyarakat terkait Covid-19. Pernyataan Jokowi pada momentum tersebut bisa menjadi upaya untuk meredam kepanikan rakyat dan sekaligus meningkatkan kewaspadaan dengan menjaga kebersihan diri.

Strategi perbaikan reputasi yang ada pada keterangan pers kali ini ialah Diminish, berupa Justification. Presiden mencitrakan Covid-19 tidak seseram apa yang diberitakan selama ini. Jokowi menyatakan bahwa sebagian besar yang tertular sembuh dan pulih. Sementara dari kajian SCCT menggambarkan penggunaan strategi Adjusting Information berupa penjelasan situasi terkini pandemi Covid-19 secara global dan bagaimana penanganan yang telah diterapkan terhadap 2 kasus pertama Covid-19 di Indonesia berpadu dengan Instructive Information berbentuk penggunaan masker bagi masyarakat yang 
sakit. Sedangkan strategi respons yang dijalankan yakni, Diminish dalam bentuk Justification bahwa pola Covid-19 serupa dengan apa yang terjadi pada saat SARS melanda.

\section{Simpulan}

Wacana strategi komunikasi krisis pemerintah sejak fase prakrisis hingga krisis mengalami perubahan berarti dari segi kajian SCCT. Pada fase prakrisis, pernyataan pejabat publik khususnya dalam hal ini Presiden Jokowi dan Menteri Kesehatan Terawan Agus Putranto mengarah pada bentuk - bentuk Deny dan Diminish. Sembari tetap menyertakan strategi komunikasi berupa Adjusting Information dan Instructive Information demi memberikan informasi kepada publik agar tetap tenang dan waspada.

Namun pada fase krisis, komunikasi pemerintah bergeser dalam rupa pernyataan Diminish saja dimana Justification bahwa Covid-19 tidak semenakutkan apa yang diberitakan menjadi gagasan utama yang muncul pada pernyataan Presiden Jokowi dan Jubir dr. Achmad Yurianto. Secara garis besar fase ini juga memberikan gambaran lebih tegas tentang proyeksi kebijakan pemerintah dalam menangani Covid-19.

Bisa dipahami bahwa strategi komunikasi krisis pemerintah dalam menghadapi ancaman Covid-19 memang tidak maksimal. Terutama pada fase prakrisis dimana pada saat itu banyak pernyataan pejabat publik yang tidak fokus dan justru terkesan meremehkan potensi ancaman Covid-19. Padahal pada fase prakrisis inilah penerapan komunikasi krisis wajib segera ditanamkan. Sebagaimana dinyatakan oleh Kriyantono (Lestari, 2013) bahwa fungsi implementasi komunikasi krisis diantaranya ialah mengurangi resiko kepanikan dan kekhawatiran publik, mengurangi spekulasi yang muncul dari diskursus publik.

Dalam perspektif SCCT, strategi komunikasi krisis yang pemerintah jalankan sendiri berkisar pada Deny dan Diminish. Padahal berdasarkan rekomendasi strategi respons, tipe krisis yang terjadi berupa pandemi termasuk ke dalam Cluster Natural Disaster yang memiliki atribusi tanggung jawab minimal bagi pemerintah. Strategi komunikasi Adjusting dan Instructive Information sebenarnya sudah cukup dalam membangun komunikasi krisis yang efektif dengan masyarakat.

Berikutnya, perlu ditelisik lebih jauh bagaimana evaluasi komunikasi krisis pada fase krisis dan pascakrisis nanti. Menarik pula untuk disimak bagaimana curah kontribusi penambahan jubir percepatan penanganan Covid-19 menjadi dua orang terhadap efektivitas komunikasi krisis yang dibangun. Riset mengenai dimensi lainnya dari AWK Van Dijk yakni kognisi sosial menarik untuk diteliti lebih jauh demi menyediakan kerangka lebih utuh terkait wacana kritis yang berlangsung selama masa pandemi Covid-19 di Indonesia. 


\section{Daftar Pustaka}

Abadi, A. P. (2020). Kasus Covid-19 di Indonesia Meluas, Hasil Kerja Santai Pemerintah. Tirto.Id. https://tirto.id/kasus-covid-19-di-indonesia-meluashasil-kerja-santai-pemerintah-eGUA

Aida, N. R. (2020). Rekap Perkembangan Virus Corona dari Waktu ke Waktu. Kompas.Com.

https://www.kompas.com/tren/read/2020/01/28/054600665/rekapperkembangan-virus-corona-wuhan-dari-waktu-ke-waktu?page=all

Aulawi, A. (2020). Dibangun dalam Waktu Singkat, Ini 5 Fakta Pembangunan RS Khusus Corona di Pulau Galang. Akurat.Co. https://akurat.co/news/id1068356-read-dibangun-dalam-waktu-singkat-ini-5-fakta-pembangunanrs-khusus-corona-di-pulau-galang

Bangun, O. P. (2013). Analisis Nuansa Makna Kata MOU dan ATO Dalam Kalimat Bahasa Jepang (Issue Imi). Universitas Sumatera Utara.

Christin, M., Hidayat, D., \& Rachmiatie, A. (2021). Construction of Social Reality for Physical Distancing During the COVID-19 Pandemic. Komunikasi, 13(1), 10-19. https://journal.untar.ac.id/index.php/komunikasi/article/view/9612/7010

Colangelo, M. (2020). Deep Analysis Of Global Pandemic Data Reveals Important Insights. https://www.forbes.com/sites/cognitiveworld/2020/04/13/covid-19complexity-demands-sophisticated-analytics-deep-analysis-of-globalpandemic-data-reveals-important-insights/?sh $=269 \mathrm{a} 626 \mathrm{e} 2 \mathrm{f} 6 \mathrm{e}$

Coombs, T. W., \& Holladay, S. J. (2011). The Handbook of Crisis Communication (1st ed.). London:Willey-Blackwell.

Coombs, W. T. (2007). Protecting Organization Reputations During a Crisis: The Development and Application of Situational Crisis Communication Theory. Corporate Reputation Review, 10(3), 163-176. https://doi.org/10.1057/palgrave.crr.1550049

Covid19, G. T. (2020). Covid19 di Indonesia. https://covid19.go.id/storage/app/uploads/public/5ea/fda/8e2/5eafda8e290 55216826912.jpg

Devlin, E. (2007). Crisis Management Planning and Execution. Florida:Auerbach Publications.

Dhyaksa, A. (2020). 11 Poin Penting Kebijakan Ekonomi Jokowi Menghadapi Wabah Corona. Bisnis.Com. https://ekonomi.bisnis.com/read/20200401/9/1220676/11-poin-pentingkebijakan-ekonomi-jokowi-menghadapi-wabah-corona-

Fakhruroji, M., Tresnawaty, B., Sumadiria, A. S. H., Risdayah, E., \& Kunci, K. (2019). Strategi Komunikasi Publik Penanganan COVID-19 di Indonesia : Perspektif Sosiologi Komunikasi Massa dan Agama. Ilmu Komunikasi UIN Sunan Gunung Djati Bandung, 1(1), 1-11.

Fearn-banks, K. (2011). Crisis Communications: A Casebook Approach, Fourth Edition (4th ed.). Routledge. 
Fitriyah, E. (2013). Analisis Kesalahan Penggunaan Kata Ganti Orang Dalam Karangan Narasi Siswa Kelas XI.1 Semester Ganjil SMA Muhammadiyah Sawangan Depok Jawa Barat Tahun Pelajaran 2013/2014 [UIN Syarif Hidayatullah]. lib.unnes.ac.id/21369/1/3201409047-S.pdf\%0A\%0A

Hamad, I. (2006). Komunikasi sebagai Wacana. Mediator: Jurnal Komunikasi, 7(2), 259-268. https://doi.org/10.29313/mediator.v7i2.1282

Hamad, I. (2007). Lebih Dekat dengan Analisis Wacana. Mediator: Jurnal Komunikasi, 8(2), 325-344. https://doi.org/10.29313/mediator.v8i2.1252

Hancock, B., Ockleford, E., \& Windridge, K. (2007). An Introduction to Qualitative Research. In Qualitative Research (Vol. 4th, p. 504). The NIHR RDS EM / YH. https://doi.org/10.1109/TVCG.2007.70541

Ismail, S. (2008). Analisis Wacana Kritis: Alternatif Menganalisis Wacana. Bahas. https://doi.org/https://doi.org/10.24114/bhs.v0i69TH\%20XXXV.2430

Juditha, C. (2018). Fenomena Trending Topic Di Twitter: Analisis Wacana Twit \#Savehajilulung. Jurnal Penelitian Komunikasi Dan Pembangunan, 16(2), 138. https://doi.org/10.31346/jpkp.v16i2.1353

Kementerian Luar Negeri. (2020). Langkah Dan Upaya Pemerintah Indonesia Dalam Menangani Dan Menghadapi Virus Novel Corona 2019 (N-COV). Kemlu.Go.Id. Langkah Dan Upaya Pemerintah Indonesia Dalam Menangani Dan Menghadapi Virus Novel Corona 2019 (N-COV)

Kintsch, W., \& Dijk, T. A. Van. (1978). Toward a Model of Text Comprehension and Production. Psychological Review, 85(5).

KSP. (2020). Protokol Komunikasi Publik. Ksp.Go.Id. http://ksp.go.id/wpcontent/uploads/2020/03/Protokol-Komunikasi-COVID-19.pdf

Kustiyono, P. S. (2010). Strategi Resistensi Terhadap Budaya Populer Pada Kolom "Parodi" Samuel Mulia di Harian Kompas (Sebuah Analisis Wacana Kritis). Universitas Sebelas Maret Surakarta.

Lado, C. R. (2014). Analisis Wacana Kritis Program Mata Najwa "Balada Perda" Di Metro TV. JURNAL E-KOMUNIKASI, 2(2).

Laksana, E. M. (2020). Achmad Yurianto jadi Jubir Penanganan Covid-19. Antaranews.Com. file:///D:/Anton Surahmat/PERKULIAHAN/Tesis/Paper UNPAD/Subjek Penelitian/Krisis/Achmad Yurianto jadi Jubir Penanganan Covid-19 - HalloIndo.html

Lestari, D. I. (2013). Penerapan Strategi Komunikasi Krisis Terhadap krisis Akibat Pemberitaan Media Tentang Kasus Koripsi Pengadaan Pupuk. Jurnal Penelitian Ilmu Komunikasi, 1-17.

LIPI. (2020). Dampak Wabah Corona untuk Perekonomian Indonesia. Lipi.Go.Id. http://lipi.go.id/berita/dampak-wabah-corona-untuk-perekonomianindonesia/21964

Lipsitch, M., Buckee, C., Taylor, A., Nechus, R., \& PM, D. S. (2020). Using predicted imports of 2019-nCoV cases to determine locations that may not be identifying all imported cases. Journal MedRxiv, 21(1), 1-9. https://doi.org/10.1016/j.solener.2019.02.027 
Mardikantoro, H. B., \& Santoso, B. W. J. (2017). Korupsi Dalam Konstruksi Media: Analisis Tekstual Pemberitaan Korupsi di Televisi Swasta Nasional Indonesia Dalam Perspektif Analisis Wacana Kritis Van Dijk. PIBSI, November, 269-285.

Mas'udi, W., \& Winanti, P. S. (Eds.). (2020). Tata Kelola Penanganan Covid-19 di Indonesia: Kajian Awal. Gadjah Mada University Press.

Matheson, D. (2005). Media discourses: Analysing Media Texts. In London: Edward Arnold (1st ed.). McGraw-Hill.

Mawardi, I. (2020). Ini Daftar 37 Pernyataan Blunder Pemerintah Soal Corona Versi LP3ES. Detik.Com. file:///D:/Anton Surahmat/PERKULIAHAN/Tesis/Paper UNPAD/Subjek Penelitian/Ini Daftar 37 Pernyataan Blunder Pemerintah Soal Corona Versi LP3ES Halaman 2.html

Nurlaily, A. S. (2019). Unsur Seksualitas Yang Direpresentasikan Tokoh Novel Pasung Jiwa Karya Okky Madasari: Analisis Wacana Kritis Teun a. Van Dijk. METASASTRA: Jurnal Penelitian Sastra, 11(2), 145. https://doi.org/10.26610/metasastra.2018.v11i2.145-156

Pramudiarja, A. U. (2020). Indonesia Kebal Corona Covid-19, Menkes: Semua Karena Do'a. Detik.Com. https://health.detik.com/berita-detikhealth/d4900600/indonesia-kebal-corona-covid-19-menkes-semua-karena-doa

Priatmojo, G. (2020). Positif Terjangkit, Menhub Budi Karya Pernah Berkelakar Soal Kebal Corona. Suara.Com. https://www.suara.com/jogja/2020/03/14/212836/positif-terjangkitmenhub-budi-karya-pernah-berkelakar-soal-kebal-corona

Keppres No. 7 Tahun 2020, (2020).

Peraturan Presiden No. 52 Tahun 2020, (2020).

Rahayu, L. S. (2020). "Harvard" Sebut Corona Seharusnya Sudah Masuk RI, Menkes: Itu Menghina. Detik.Com. https://news.detik.com/berita/d4894445/harvard-sebut-corona-seharusnya-sudah-masuk-ri-menkes-itumenghina

Ramdhani, J. (2020). WHO Apresiasi RI soal Evakuasi-Observasi 238 WNI dari Wuhan Terkait Corona. Detik.Com. https://news.detik.com/berita/d4900667/who-apresiasi-ri-soal-evakuasi-observasi-238-wni-dari-wuhanterkait-corona

Resti, Y. (2020). Covid-19: "Indonesia berpotensi resesi" - dampak ekonomi "jauh lebih berat" ketimbang krisis moneter 1998. Bbc.Com.

The Conversation. (2020). Analisis: Pemerintah masih bisa perbaiki komunikasi krisis pandemi yang sejauh ini gagal. Theconversation.Com. https://theconversation.com/analisis-pemerintah-masih-bisa-perbaikikomunikasi-krisis-pandemi-yang-sejauh-ini-gagal-134542

The Guardian. (2020). China virus death toll hits 82 as 73 test negative in UKas it happened. Theguardian.Com. https://www.theguardian.com/world/live/2020/jan/27/coronavirus-chinadeath-toll-climbs-to-80-with-more-than-2700-cases-liveupdates?page=with:block-5e2e22db8f0879d539eff98f\#liveblog-navigation 
University of Minnesota. (2016). Communication in the Real World: An Introduction to Communication Studies. University of Minnesota Libraries Publishing edition. https://doi.org/10.24926/8668.0401

Van Dijk, T. (1993). Principals of Discourse Analysis. Discourse and Society, 4(2), 249-283.

van Dijk, T. A. (1983). Discourse Analysis: Its Development and Application to the Structure of News. Journal of Communication, 33(2), 20-43. https://doi.org/10.1111/j.1460-2466.1983.tb02386.x

Van Dijk, T. A. (2006). Discourse, context and cognition. Discourse Studies, 8(1), 159-177. https://doi.org/10.1177/1461445606059565

World Economic Forum. (2020). Key milestones in the spread of the coronavirus pandemic.

Weforum.Org. https://www.weforum.org/agenda/2020/04/coronavirus-spread-covid19pandemic-timeline-milestones/

Yahya, A. N. (2020). Ada 800 Rumah Sakit Rujukan di Indonesia untuk Tangani Pasien Covid-19.

Kompas.Com. https://nasional.kompas.com/read/2020/04/15/18344001/ada-800-rumahsakit-rujukan-di-indonesia-untuk-tangani-pasien-covid-19 